\title{
Porokeratosis of Mibelli - literature review and a case report ${ }^{*}$ Poroqueratose de Mibelli - revisão da literatura e relato de um caso
}

\author{
Flávia Regina Ferreira ${ }^{1}$ \\ Fernando Augusto Nogueira Mendes Tagliarini ${ }^{2}$
}

\author{
Leopoldo Duailibe Nogueira Santos² \\ Marcia Lanzoni de Alvarenga Lira ${ }^{3}$
}

DOI: http://dx.doi.org/10.1590/abd1806-4841.20132721

\begin{abstract}
Porokeratosis is a disorder of epidermal keratinization characterized by annular plaques with an atrophic center and hyperkeratotic edges, and includes a heterogeneous group of disorders that are mostly inherited in an autosomal dominant form. This report describes a 5 year-old female patient, with porokeratosis of Mibelli confirmed histopathologically. The rarity of this disorder, its clinical exuberance and the destructive character of the lesions, as well as the facial and mucosal involvements, unusual in this form of porokeratosis, and also its onset in early childhood motivated this report.
\end{abstract}

Keywords: Child; Parakeratosis; Porokeratosis

Resumo: A poroqueratose é uma desordem da queratinização epidérmica caracterizada por placas anulares com centro atrófico e bordas hiperqueratóticas, e inclui um grupo heterogêneo de desordens que são na sua maioria herdadas de forma autossômica dominante. O presente caso refere-se a uma paciente feminina de 5 anos de idade, com poroqueratose de Mibelli confirmada histologicamente. A raridade desta desordem, a exuberância clínica e o caráter destrutivo das lesões, o acometimento facial e mucoso pouco usuais nesta forma de poroqueratose e o início na infância precoce motivaram este relato.

Palavras-chave: Criança; Paraceratose; Poroceratose

\section{INTRODUCTION}

Porokeratosis is a primary disorder of epidermal keratinization, characterized by annular plaques with an atrophic center and hyperkeratotic edges. ${ }^{1,2}$ The cornoid lamella, a column of parakeratotic cells that occupies the small epidermal invaginations, constitutes a characteristic histopathological finding, primordial for its diagnosis. ${ }^{1-7}$

Porokeratosis include a group of heterogeneous disorders that represent diverse phenotypic expressions of the same genetic defect, which is mainly inherited in an autosomal dominant form. ${ }^{1,3}$

Porokeratosis can be classified in localized and disseminated forms (Figure 1). ${ }^{2}$

Classic porokeratosis, the most common variant, was first described in 1893 by Vittorio Mibelli, hence the name porokeratosis of Mibelli (PM) ${ }^{1,3,4,6,8}$ The first Brazilian description was made in 1934 by Niemayer. ${ }^{9}$ This is a rare, chronically progressive disease, arising either from an autosomal dominant inheritance or, more commonly, appearing as a random form. ${ }^{1,3}$ It is more frequent in males, starting in childhood or adolescence. ${ }^{1,3,5,6,9}$ Lesions may affect any tegument part, being more prevalent in the trunk and extremities..$^{2-4,10}$

The rarity of this disorder, its clinical exuberance and the destructive character of the lesions, as well as the facial and mucosal involvements, unusual in this form of porokeratosis, and also its start in early childhood motivated this report.

Received on 28.04.2013.

Approved by the Advisory Board and accepted for publication on 30.05.2013

* Work performed at the Dermatology Service of the University Hospital of Taubaté - University of Taubaté (HUT-UNITAU) - Taubaté (SP), Brazil. Conflict of interest: None Financial Support: None

MD, MSc at São Paulo Federal University - Paulista Medical School (UNIFESP-EPM) - Assistant Professor of Dermatology Discipline in the Medicine Department of the University of Taubaté (UNITAU) - Taubaté (SP), Brazil.

MD - Specialization (in course) at the Dermatology Service of the University Hospital of Taubaté - University of Taubaté (HUT-UNITAU) - Taubaté (SP), Brazil.

Specialist in Pathological Anatomy - Assistant professor of the Pathology Discipline of the Medicine Department in the Medicine Department of the University of Taubaté (UNITAU) - Taubaté (SP), Brazil. 


\section{CASE REPORT}

This is a five year-old, brown-skinned female patient, with a history of developing erythematoushyperchromic plaques with slightly elevated edges and atrophic center located on the face (malar areas bilaterally, inferior eyelids, nose and chin) since the age of one and a half years (Figures 2 and 3). Similar lesions were presented, although with more elevated borders, on the dorsal area of the left-hand and the lateral region of the second right-hand digit (Figure 4). Dermatologic examination showed that the inferior palpebral lesions extended to the mucosa of the eye, starting an ectropion growth and in the left nasal lesion there was a meliceric crust, by a recent impetigo process (already in treatment). There were not any relevant personal antecedents. Family members were also examined and no important cutaneous alterations were found.

Histopathological examination of the material collected from the dorsal area of left hand revealed cornoid lamella and hypogranulosis, confirming the diagnosis of porokeratosis (Figure 5).

\section{DISCUSSION}

Classic porokeratosis or porokeratosis of Mibelli (PM) is a chronic, progressive dermatosis, that may rarely evolve with spontaneous remission. ${ }^{3,4,8}$ Regarding the mode of inheritance, it may arise in an autosomal dominant form, more commonly in a random form, which we believe was the case for this patient, since there were not any relatives affected by the disease. ${ }^{1,4}$ Nonetheless, a genetic evaluation for this patient and her family is advisable, to address genetic counseling issues for the future.

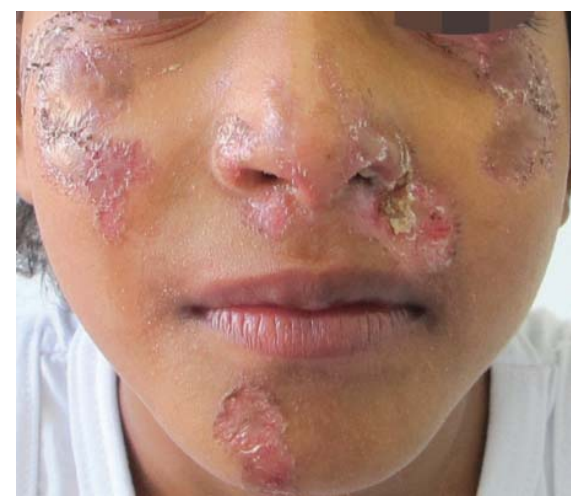

Figure 2:

Face - erythematous-hyperchromic plaques with slightly elevated edges and atrophic center
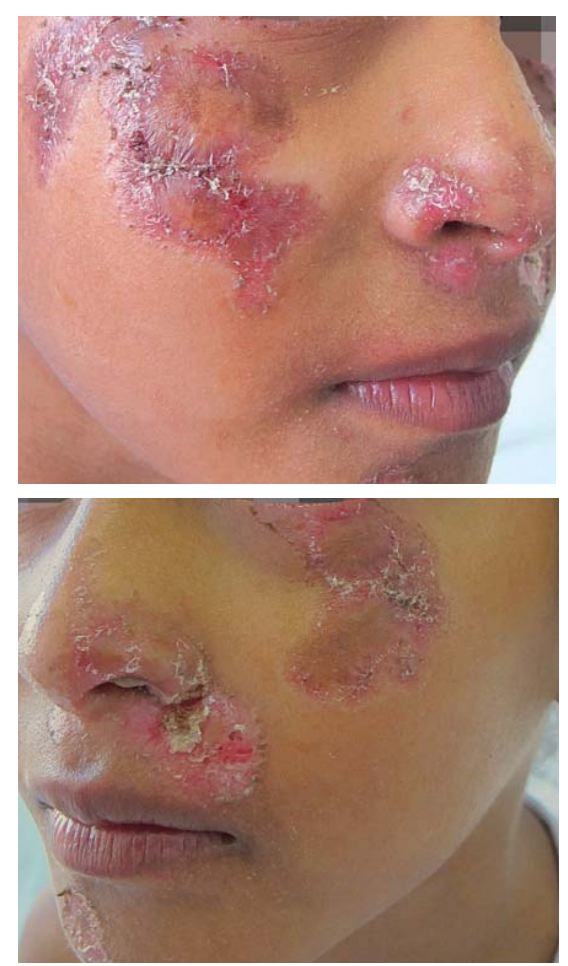

Figure 3: Details of the facial lesions

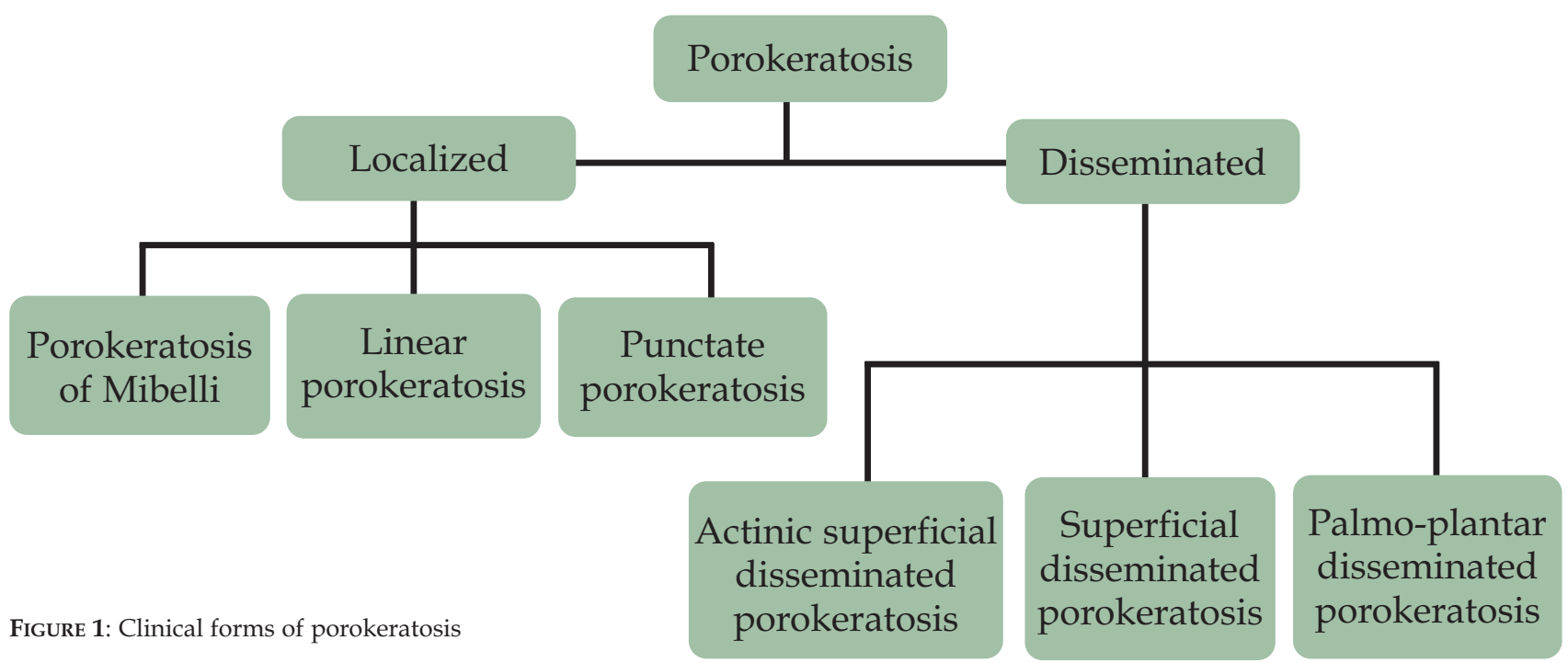




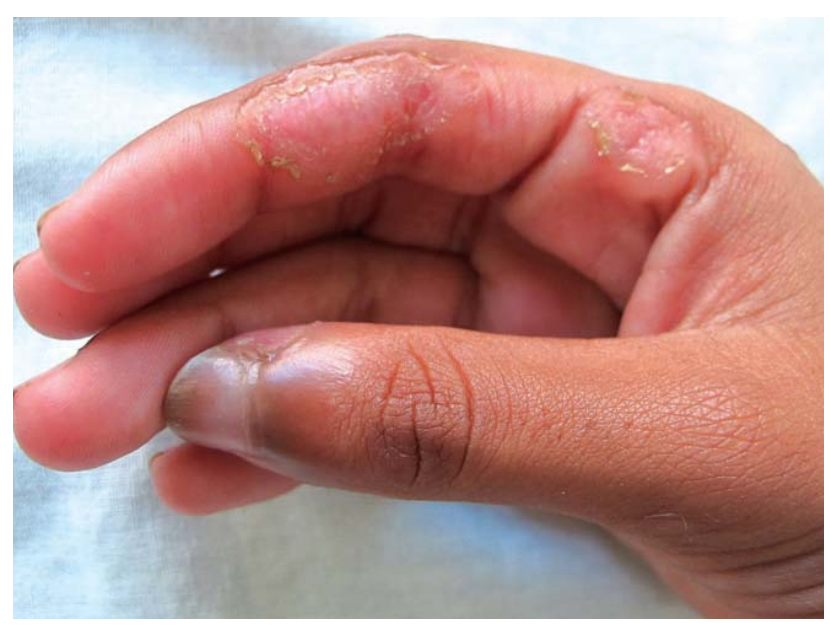

FIGURE 4: Lateral region of the second right-hand digit- erythematous plaques with elevated edges and atrophic center

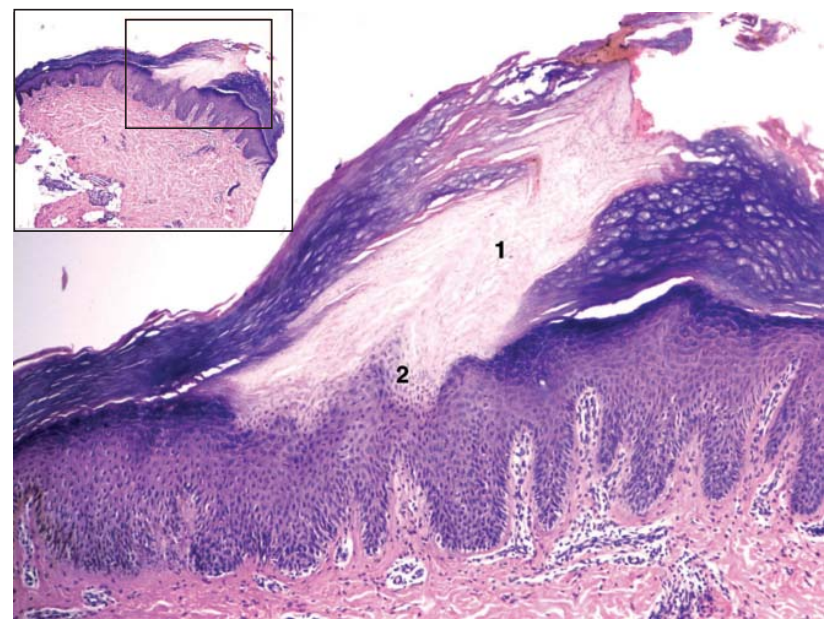

FIGURE 5: Histopathological exam: cornoid lamella (1) and hypogranulosis (2). (HE 400X)

PM consists of one or more plaques, usually a small number of them, which may occur anywhere in the body, more frequently in extremities, especially hands and feet, with unilateral distribution. ${ }^{1,3-5}$ Other areas, such as neck, shoulders and genitals may also be affected. The occurrence of facial and mucosal lesions, as observed in this patient, is rare. ${ }^{3}$

It starts, in general, during childhood or adolescence, being more prevalent in males (ratio of 2$3: 1)^{2,3,8,10}$ It is also more frequent in Caucasians. ${ }^{7}$ Lesions are asymptomatic with an indolent evolution. ${ }^{3}$ The case reported here regards a female, brown-skinned patient with swiftly and aggressively evolving lesions, thus disagreeing with the literature data stated above.
Differential diagnosis of PM must address mainly: psoriasis, Bowen's disease, squamous cell carcinoma and melanoma. Less commonly and depending on different presentations and locations: lichen striatus, lichen planus annulare, lichen sclerosus et atrophicus, plane warts, cutaneous tuberculosis, nevus comedonicus, inflammatory linear verrucous epidermal nevus (ILVEN), pityriasis rubra pilaris, acrokeratosis verruciformis, xerosis, lentigines, elastosis perforans serpiginosa, Darier's disease, linear scleroderma, actinic keratosis, seborrheic keratosis, lupus erythematosus, basal cell epithelioma, porokeratosis eccrine ostial, and dermal duct nevus. ${ }^{4}$ In this case we emphasize lupus vulgaris and lupus erythematosus discoid, especially if considering only the facial lesions.

Diagnostic confirmation is achieved through histopathological examination with the finding of the cornoid lamella. ${ }^{1-8}$ The development of high-resolution non-invasive imaging techniques, such as the optical coherence tomography and the confocal fluorescence microscopy, has permitted the in-vivo identification of cornoid lamella. ${ }^{3,10}$

The association of cornoid lamella to local dysplastic alterations suggests that this dermatosis may result from the localized and clonal expansion of abnormal keratocytes. Contributing factors to the clonal proliferation may be intrinsic genetically determined ones (chromosome 3p 12-14 instability) or extrinsic factors (such as immunosuppression, ultraviolet radiation exposure, infectious agents, mechanical trauma and drugs). 3,10

PM malignization was first described by Vigne in $1942^{2}$ and may occur in about $7 \%$ of the affected patients. ${ }^{2,3}$ Squamous cell carcinoma (SCC) is the most commonly associated tumor. ${ }^{3,4,10}$ The association with Bowen's disease and basal cell carcinoma (BCC) is also reported..$^{2-4,6,8,10}$ This oncogenic potential may be the result of an increased p53 expression in the keratinocytes near the cornoid lamella. ${ }^{3}$

Treatment for PM should be individualized considering the aesthetic and functionality, potential to malignization and the patient's preferences.

Surgery is the elective treatment, depending on the number and size of the lesions. Other possible approaches include cryotherapy (liquid nitrogen), $\mathrm{CO}_{2}$ laser, dermabrasion, oral and topical retinoids, topical vitamin D3 analogs, keratolytic agents, topical and intralesional corticoids, topical 5-fluorouracil and most recently $5 \%$ imiquod, $3 \%$ topical sodium diclofenac and photodynamic therapy. ${ }^{1-4,8-10}$ In this case, the authors intend to start the treatment with topical tretinoin. This choice is justified by the age of the patient, the availability of the medication in this Institution and the good results reported in the literature. ${ }^{7,10}$

Also of great importance is the education regard- 
ing photoprotection and the long-term follow-up of these patients. Response to different treatments is varied and usually temporary, with frequent relapses. ${ }^{3,4,8}$

The authors highlight the exuberance of the case reported here and destructive character of the lesions, also the facial and mucosal involvements, uncommon in this form of porokeratosis and the age of onset (one and a half years old), this being perhaps the youngest case already described in the literature.

\section{REFERENCES}

1. Gutierrez EL, Galarza C, Ramos W, Tello M, De Paz PC, Bobbio L, et al. Facial porokeratosis: A series of six patients. Australas J Dermatol. 2010;51:191-4.

2. Chen TJ, Chou YC, Chen CH, Kuo TT, Hong HS. Genital porokeratosis: a series of 10 patients and review of the literature. Br J Dermatol. 2006;155:325-9.

3. Laureano A, Macias VC, Pacheco FA. Poroqueratose de mibelli - um caso clínico (Porokeratosis of Mibelli - a clinical case). Revista SPDV. 2012;70:209-12.

4. Dal Santo Francisco B, Salamí OAR, Santos RB, Jorge MA, Gonzaga HFS. Poroqueratose de Mibelli: uma condição que pode evoluir para neoplasia maligna (Porokeratosis of Mibelli: as a keratotic disorder at risk for malignant transformation). RBM Rev Bras Med. 2011;68:7-9.

5. Mukhopadhyay AK. Simultaneous occurrence of disseminated superficial, linear and hypertrophic verrucous forms of porokeratosis in a child. Indian J Dermatol Venereol Leprol. 2004;70:364-6.

6. Bohórquez L, Arango Al, Cadena AZ, Ruiz AC. Poroqueratosis superficial diseminada de la cara (Superficial disseminated porokeratosis of the face). Rev Asoc Colomb Dermatol. 2010;18: 45-6.

7. Heras C, Mantovani K, Martelotte M, Rabay FMO, Campana M. Poroqueratose de Mibelli (Porokeratosis of Mibelli). An Bras Dermatol. 2005;80:S137.

8. Zanini M. Poroceratose de Mibelli (Porokeratosis of Mibelli). Med Cutan Iber Lat Am. 2011;39:126-8.

9. Herrera RP, Mendonça IRSM, Azulay RD. Poroqueratose de Mibelli - Revisão bibliográfica e relato de um caso clínico com forma verrucosa (Porokeratosis of Mibelli bibliographic review and report of clinical case with verrucous form). An Bras Dermatol. 1992; 67:155-8.

10. Sertznig P, von Felbert V, Megahed M. Porokeratosis: present concepts. J Eur Acad Dermatol Venereol. 2012;26:404-12.

\author{
MAILING ADDRESS: \\ Flávia Regina Ferreira \\ Avenida Granadeiro Guimarães, 270 - Centro \\ 12020-130 - Taubaté - SP \\ Brazil \\ E-mail: dermagica@uol.com.br
}

How to cite this article: Ferreira FR, Santos LDN, Tagliarini FANM, Alvarenga Lira ML. Porokeratosis of Mibelli literature review and a case report. An Bras Dermatol. 2013;88(6 Suppl 1):S179-82. 